\title{
Maternal Malnutrition Diet During Lactation Period Leads to Incomplete Catch-Up Growth in Femur of the Pups at Adulthood
}

\author{
Restricción Alimentaria Materna Durante la Lactancia Conduce a la Recuperación \\ del Crecimiento Incompleto en el Fémur de las Crías en la Edad Adulta
}

Monique S. D. Babinski"; Cristiane F. Ramos"*; Rodrigo M. P. Fernandes ${ }^{* * * *}$; Gilberto P. Cardoso ${ }^{*, * * * *}$ \& Marcio A. Babinski",****

BABINSKI, M. S. D.; RAMOS, C. F.; FERNANDES, R. M. P.; CARDOSO, G. P. \& BABINSKI, M. A. Maternal malnutrition diet during lactation period leads to incomplete catch-up growth in femur of the pups at adulthood. Int. J. Morphol., 34(1):71-77, 2016.

SUMMARY: The aim of this study was to evaluate the effects of maternal protein and energy restriction during lactation, analyzing on morphological dimensions whether there was catch-up growth through normative nutrition restored, as well as on mechanical axis of femur of the offspring at adulthood. At parturition, Wistar rat dams were randomly assigned to the following groups: 1) control group (C) - free access to a standard laboratory diet containing $23 \%$ protein, 2) protein-energy restricted group (PER) - free access to an isoenergetic, protein-restricted diet containing $8 \%$ protein, and 3) energy-restricted group (ER) - fed with restricted amounts of a standard laboratory diet. At weaning, all pups were separated of dams and received free access to a standard laboratory diet containing 23 $\%$ protein until 180 days, when the rats were anesthetized and sacrificed. The dimensions of excised pup femur were measured directly using pre-established anatomical points. Morphometric analysis of the femur (macroscopic) showed that most of the measurements in the ER and PER groups were significantly lower than in the control group, with the greatest reductions occurring in the PER group and several structural abnormalities. Our results show that protein and energy restriction during lactation leads to an incomplete catch-up growth in adulthood. The femur showed significant reduction in most of the parameters in the two treated groups, particularly the PER group, when compared to the control group.

KEY WORDS: Rats; Femur; Undernutrition; Growth; Morphometry.

\section{INTRODUCTION}

Nearly 805 million people are estimated to suffer from malnutrition. Twenty-five percent of children experience stunted growth due to malnutrition, whilst approximately 45 $\%$ of deaths in children under the age of five can be correlated with starvation (de Onis et al., 2012). Thus, childhood malnutrition remains a common world health problem and is a major contributor to impaired childhood growth and development as well as mortality. Typical mortality rates of children suffering from severe protein-energy malnutrition are 20-30\%, which is a high percentage (de Onis et al.).

On other hand, in hospitalized patients, the reported prevalence of malnutrition is as high as $75 \%$ (Correia et al., 2013). In addition, hospitalization further worsens the nutritional status. Malnutrition has been associated with increases in the risk of in-hospital morbidity/ mortality, the length of hospital stay, the costs, and the use of health care resources (Naber et al., 1997). Therefore, studying malnutrition is relevant and timely.

Some studies have shown that the nutritional status of the mother during gestation and lactation is essential to normal growth and development in humans (Baker, 2000) and in experimental animals (Passos et al., 2000; Teixeira et al., 2002; Fernandes et al., 2007, 2008; Andrade et al., 2012). Previous studies have shown that maternal malnutrition during lactation can change milk composition (Passos et al.), serum hormone levels (Teixeira et al.). Interestingly, some of these changes can persist into adulthood (Houdijk et al., 2003; Oreffo et al., 2003), which seems to confirm the concept of programming (metabolic imprinting) (Lucas, 1998; Waterland \& Garza, 1999).

\footnotetext{
* Post-Graduation in Medical Sciences, Fluminense Federal University (UFF), Niterói, Brazil.

** Department of Anatomy, Biomedical Center, State University of Rio de Janeiro (UERJ), Rio de Janeiro, Brazil.

*** Department of Morphology, Biomedical Center, Fluminense Federal University, Niterói, Brazil.

**** Department of Internal Medicine. Fluminense Federal University (UFF), Niterói, Brazil.
} 
However, some authors reported that the protein malnutrition leads to growth retardation that can be reversed through catch-up growth, once normative nutrition is restored (Boersma \& Wit, 1997; Boyer et al., 2005; Jones et al., 2011). Since growth is a dynamic process, catch-up capacity is likely influenced by the maturity and duration and type of the insult (Jones et al.). Catch-up growth exists in several different species for a multitude of different growth impediments (Boersma \& Wit; Boyer et al.). Despite this broad prevalence, removal of a growth insult does not always result in catchup growth (Houdijk et al., 2003; Oreffo et al.).

The bone is one of the portions of the body that is critically affected by malnutrition (Boersma \& Wit; Cooper et al., 2002; Houdijk et al., 2003; Oreffo et al.; Boyer et al.; Fernandes et al., 2007, 2008).

This disorder produces biochemical alterations leading to poor growth (Rodriguez et al., 1998; Medeiros et al., 2002). In turn, Cooper et al. reported in epidemiological studies that poor growth during fetal, infancy and childhood periods are associated with a decreased bone mass and a larger risk of developing fractures.

The composition of the bone of rats is similar to that of those in the humans. Thereby, the rat has been widely used and is considered a good model for nutrition when studying the human skeletal system and major metabolic diseases, as well as osseous disorders (Oreffo et al.; Boyer et al.; Fetoui et al., 2008). In this way, the objective of present study was to investigate the effects of maternal protein and energy malnutrition during lactation, analyzing on morphological dimensions whether there was a catch-up growth through normative nutrition restored, as well as on mechanical axis of femur of the offspring at adulthood.

\section{MATERIAL AND METHOD}

The study design and its experimental protocols were approved by the Animal Care and Use Committee of the State University of Rio de Janeiro, and were in accordance with the American Physiological Society guidelines (Bayne, 1996). The experiments described here were done in compliance with the general guidelines of the Brazilian College for Animal Experimentation (COBEA).

Animals. Wistar rats obtained from Biomedical Center, State University of Rio de Janeiro were housed at $25 \pm 1{ }^{\circ} \mathrm{C}$ and on a $12 \mathrm{~h} \mathrm{light/dark} \mathrm{cycle} \mathrm{(lights} \mathrm{on} \mathrm{from} \mathrm{07:00} \mathrm{a.m.} \mathrm{to} \mathrm{07:00}$ p.m.) throughout the experiment. Three-month-old, six virgin female rats were housed with one male rat at a proportion of
2:1. After mating, each female was placed in an individual cage with free access to water and food until delivery. Then, the number of pups born was similar, six per pregnant rat, totaling 12 per group. All pups showed good health condition. Furthermore, no pups showed any statistical difference in body weight or linear growth.

Experimental procedures and diets. Pregnant Wistar rats were separated at delivery into three groups: 1) control group (C) - with free access to a standard laboratory diet (in grams per $100 \mathrm{~g}$ ) containing $23 \%$ protein, $68 \%$ carbohydrate, $5 \%$ lipid, $4 \%$ salts and $0.4 \%$ vitamins, 17,038.7 total energy $(\mathrm{kJ} / \mathrm{kg}) ; 2$ ) protein-energy-restricted group (PER) - with free access to an isoenergetic, protein-restricted diet containing $8 \%$ protein, and 3 ) energy-restricted group (ER) - fed with a standard laboratory diet in restricted quantities that was calculated based on average ingestion of the PER group. We have previously shown that the PER group consumed about $60 \%$ of the amount consumed by the control group, despite having free access to food (Passos et al.; Teixeira et al.; Fernandes et al., 2007, 2008; Andrade et al.). Hence, the ER and PER groups ingested essentially the same amount of food, which was measured every day.

The protein-restricted diet was prepared in our laboratory (Table I) by using the control diet with replacement of part of its protein content with cornstarch. The amount of the latter was calculated to replace the same energy content of the control diet. Vitamin and mineral mixtures were formulated to equal those found in the control diet and to meet the American Institute of Nutrition AIN93G recommendation for rodent diets (Reeves et al., 1993). Within $24 \mathrm{~h}$ of birth, excess pups were removed so that only six pups were kept per dam, as it has been shown that this procedure maximizes lactation performance (Fischbeck \& Rasmussen, 1987).

Malnutrition has started at birth (immediately postpartum), which was defined as day 0 of lactation, and has ended at weaning $(\mathrm{d} 21=21$ days post-partum). To evaluate the nutritional state, the body weight of the pups was monitored during the $21 \mathrm{~d}$ throughout the experiment (Fig. 1). After weaning (d22-d180), male pups of the same treatment group were housed in group of three animals per cage, and given unlimited access to food and water until adult period (day 180), then, the animals were anesthetized with a lethal thiopental anesthesia $(0.15 \mathrm{~mL} /$ $100 \mathrm{~g} /$ body weight) and perfused through the left ventricle with buffered saline followed by formalin solution, always in the morning. The right femur bones were excised, dissected, weighted, and fixed in formalin $4 \%$ in $0.1 \mathrm{M}$ in phosphate buffer ( $\mathrm{pH}$ 7.4), and then, assessed using two morphometric parameters. 
Table I. Composition of control and protein-restricted diets.

\begin{tabular}{|c|c|c|c|}
\hline & & Control & Protein-restricted \\
\hline Ingredients & Total protein $^{\mathrm{a}}$ & 230.0 & 80.0 \\
\hline \multirow[t]{4}{*}{$(\mathrm{g} / \mathrm{kg})$} & Corn starch & 676.0 & 826.0 \\
\hline & Soybean oil & 50.0 & 50.0 \\
\hline & Vitamin & 4.0 & 4.0 \\
\hline & Mineral & 40.0 & 40.0 \\
\hline Macronutrient & Protein & 23.0 & 8.0 \\
\hline \multirow[t]{2}{*}{ composition $(\%)$} & Carbohydrate & 66.0 & 81.0 \\
\hline & Fat & 11.0 & 11.0 \\
\hline Total energy $(\mathrm{kJ} / \mathrm{kg})$ & & 17.038 & 17.038.7 \\
\hline
\end{tabular}

aThe principal protein resources were soybean wheat, steak, fish and amino acids.

bStandard diet for rats (Nuvilab-Nuvital Ltd., Curitiba, Paraná, Brazil).

cThe protein-restricted diet was prepared in our laboratory by replacing part of the protein content of the control diet with cornstarch. The amount of the latter was calculated to replace the same energy content of the control diet.

dVitamin and mineral mixtures were formulated to meet the American Institute of Nutrition AIN-93G recommendation for rodent diets [28].

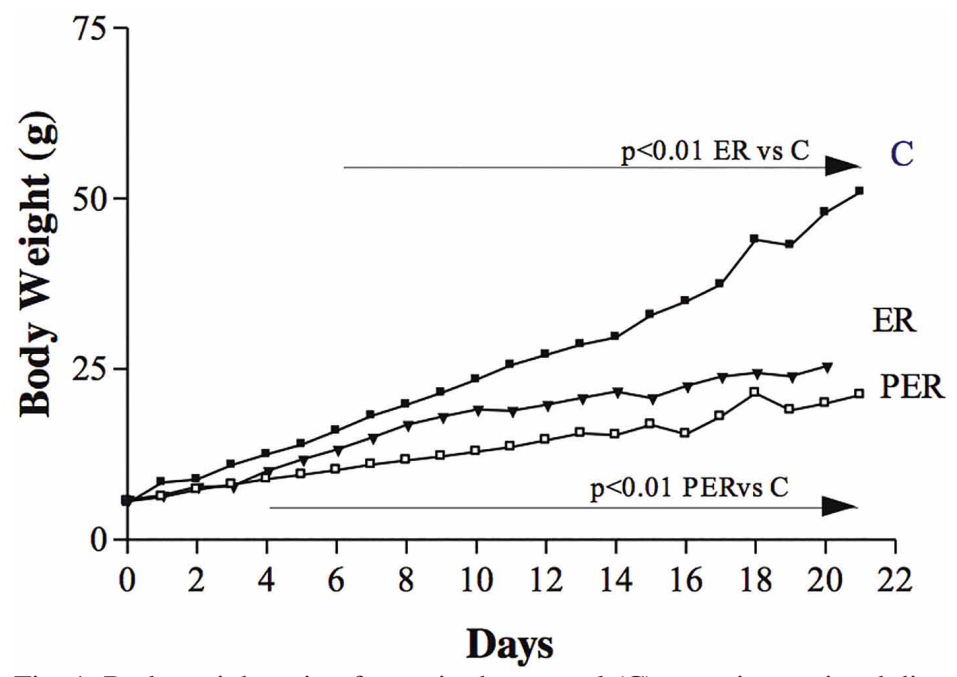

Fig. 1. Body weight gain of pups in the control (C), protein restricted diet (PER) and energy-restricted diet (ER) groups up to 21 days of age. Group $\mathrm{C}$ : free access to water and a diet containing $23 \%$ protein; group PER: free access to water and a diet containing $8 \%$ protein; group ER: free access to water and limited access to a commercial diet containing $23 \%$ protein, which corresponded to the same amount ingested in the previous day by rats in group PER. The results are the mean \pm SD of 12 pups per group.

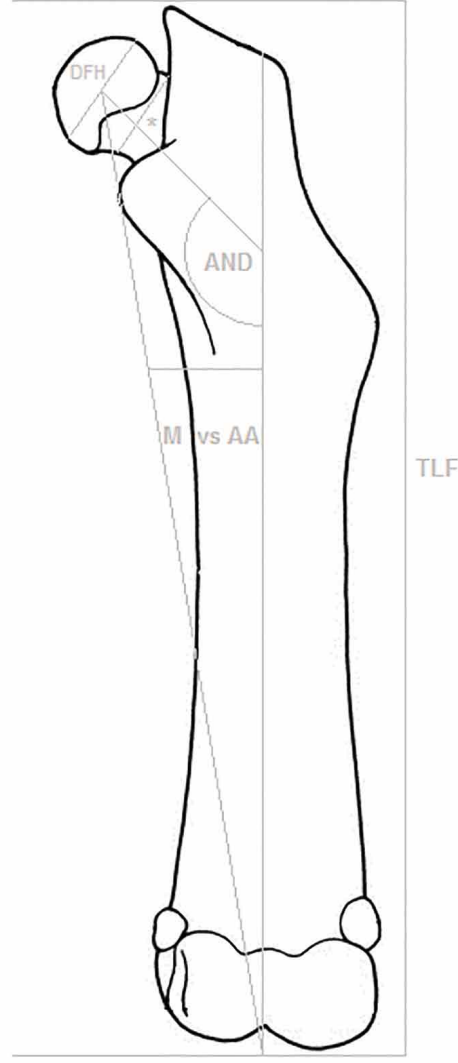

Fig. 2. Schematic drawing representing the morphometric parameters analyzed. $\mathrm{BW}=$ Body weight; FW= Femoral weight; $\mathrm{TLF}=$ Total Length of Femur; DFN $(*)=$ Diameter of Femur Neck; DFH= Diameter of Femur Head; $\mathrm{AND}=$ Angle of NeckDiaphyseal; $\quad$ MvsAA= difference between Mechanical and Anatomical Axis.
Morphometric parameters. All the femurs were assessed by roentgen exam, when the films were measured using the digital AutoCAD 2000 (USA) software. The parameters measured are illustrated in Figure 2.

Statistical analysis. Data was reported as the mean \pm standard deviation (SD). Statistical significance of experimental observations was determined by the ANOVA one-way analysis of variance, followed by Newman Keuls test to compare the 3 experimental groups. The level of significance was set at $\mathrm{p}<$ 0.05. All statistical analyses were done using GraphPad Prism 4 statistical software (GraphPad Inc., CA, USA).

\section{RESULTS}

Figure 1 shows the body weight gain of pups in the three groups. The pups of dams fed with a protein-restricted diet during lactation had lower weight gain than the control group throughout the study (up to $21 \mathrm{~d}$ of age) ( $\mathrm{p}<0.01$ ), with the difference between these two groups being $\sim 58 \%$. The pups in group ER had lower weight gain ( 46\% less) than the control group from day 6 onwards $(\mathrm{p}<0.01)$. PER group showed lower weight gain than ER group from day 2 until the end of the study $(\mathrm{p}<0.01)$. With aging, adult rats presented a 
persistent and significant reduction in body weight, as well as, in the femur weights $[\mathrm{ER}=\sim 8.9 \%$ and $\sim 21 \%$; PER $=$ $\sim 13.3 \%$ and $\sim 23 \%$; $<<0.01$ and $<0.001$; respectively] when compared to the control group (Table II). There was no significant difference between ER and PER groups.

Table II show the morphometric data of the femur bone of the offspring at adulthood, in which, presented a significant reduction in all parameters studied when compared to the control group: femoral total length $(\mathrm{p}<0.05$, ER and $\mathrm{p}<0.01 \mathrm{PER})$ (Fig. 6); neck-diaphyseal angle ( 4.4\%, p<0.001 ER and $\sim 6.1$ $\% \mathrm{p}<0.001$ PER) (Fig. 7) and a difference between mechanical and anatomical axis $(\sim 11.8 \%, \mathrm{p}<0.001$ ER and $\sim 14.7 \%$, $\mathrm{p}<0.001$ PER) (Fig. 8 and Table II). There was no significant difference between ER and PER groups.

\section{DISCUSSION}

Bone strength is determined on one hand by architectural variables like geometry, porosity, cortical thickness, and trabecular bone structure, and on the other hand by the intrinsic bone tissue properties (Turner, 2002). Since bones are vital tissues, they are subject to a variety of disorders ranging from congenital defects, malnutrition, and hormone imbalance due to degenerative and inflammatory diseases and injuries. The development is critically affected by malnutrition, and several studies have examined the effect of nutritional deficiencies on bone growth during gestation (Mehta et al., 2002), lactation (Miller \& German, 1999; Fernandes et al., 2007, 2008; Fetoui et al.; Andrade et al.) and the post-weaning period (Ramos et al., 1997; Brogan et al., 1997). Thus, growth retardation varies in accordance with the severity and duration of the nutritional deficiency (Jones et al.). It may be associated with abnormalities in body size and composition in adulthood, as well as in bone length and its mineral content (Rodriguez et al.; Medeiros et al.; Boyer et al.).
Different forms of retarded skeleton growth have been reported, depending on the type of malnutrition and/or its intensity, including the period in which stress was applied. Additionally, growth of the femur in rats may be influenced by sex, breed or strain and nutritional status (Miller \& German; Alippi et al., 2002; Mehta et al.; Fetoui et al.; Jones et al.).

The strengths of our study may be appreciated in its experimental design, the longitudinal nature of data collection, easy comparison to previous studies (Jones et al.) using identical animal husbandry protocols (Ramos et al.; Passos et al.; Teixeira et al.; Fernandes et al., 2007; Andrade et al.), and simultaneous contrast of targeted and catch-up growth (Jones et al.).

In the present study, the femur was critically affected by malnutrition. Femoral underdevelopment was observed in weaned rats whose mothers were fed PER or ER diets during lactation, as shown in Table II. In addition, those changes were accompanied by quantitative alterations in the body weight during lactation (Fig. 1 and Table II). These differences could be explained, in part, by the decrease of food intake by mothers submitted to low-protein diet observed in our experimental model. These results were in agreement with other reports, using different experimental models, which showed that the restriction in protein and calorie intake, imposed by pair-feeding process, led to differences in skeletal maturation and skeletal protein turnover as compared with animals fed ad libitum a solid standard diet (Passos et al.; Alippi et al.; Teixeira et al.; Mehta et al.; Fernandes et al., 2007; Fetoui et al.). On the other hand, the reduction of body weight and bone mass in suckling pups of PER or ER group might be related to quantitative and qualitative changes of milk composition as demonstrated by previous findings (Passos et al.), that showed that total milk fat, protein and energy available to the pups were reduced in undernourished rats.

Table II. Results of the morphometric analysis (mean \pm SD) of 12 pups per group.

\begin{tabular}{lccc}
\hline Parameters & C & ER & PER \\
\hline BW $(\mathbf{g})$ & $459.4 \pm 43.6$ & $407.6 \pm 45.28(*)$ & $414.04 \pm 31.95(* *)$ \\
FW $(\mathbf{g})$ & $1.40 \pm 0.06$ & $1.12 \pm 0.16(*)$ & $1.11 \pm 0.10(* *)$ \\
TLF $(\mathbf{m m})$ & $39.87 \pm 1.12$ & $38.95 \pm 1.18(\mathrm{~ns})$ & $38.81 \pm 1.17(\mathrm{~ns})$ \\
DFN $(\mathbf{m m})$ & $2.88 \pm 0.09$ & $2.14 \pm 0.20(*)$ & $2.12 \pm 0.12(* *)$ \\
DFH $(\mathbf{m m})$ & $4.86 \pm 0.26$ & $4.24 \pm 0.28(*)$ & $4.32 \pm 0.21\left(^{* *}\right)$ \\
AND $\left({ }^{(}\right)$ & $137.8 \pm 2.5$ & $132.2 \pm 3.5(*)$ & $130 \pm 3.5(* *)$ \\
\#MvsAA $\left({ }^{\circ}\right)$ & $10.2 \pm 0.4$ & $9.3 \pm 0.4(*)$ & $8.7 \pm 0.4(* *)$ \\
\hline
\end{tabular}

BW= Body weight; FW= Femoral weight $;$ TLF= Total Length of Femur; DFN= Diameter of Femur Neck; DFH= Diameter of Femur Head; $A N D=$ Angle of Neck-Diaphyseal; $\partial$ MvsAA $=$ difference between Mechanical and Anatomical Axis. ${ }^{*}=\mathrm{C}$ vs. PER $(\mathrm{p} \leq 0.01) * *=\mathrm{C}$ vs. ER $(\mathrm{p} \leq 0.001) . \mathrm{ns}=$ non-significant. 
Based on the present findings of an attenuated femoral dimensions development in the ER and PER groups (table II), we suggest that the femur was proportionally underdeveloped with anatomical and mechanical axis altered, as well as alterations of the diameter and angle of neckdiaphyseal in the malnourished rats. These alterations with poor growth are associated with a decreased bone mass and an increased risk of fractures (Cooper et al.). Similarly, Boyer et al. demonstrated that the femur weight was also reduced according to the nutritional deficit. Malnutrition during these important phases of development causes failure to complete bone recovery at least until $100 \mathrm{~d}$ of life in rats (Houdijk et $a l ., 2000)$ and up to 6 months of life in human beings (Engelbregt et al., 2004).

Our data unclearly demonstrated that catch-up growth is still possible after puberty [in malnourished rats by 21 days] (Table II), unlike other authors (Boersma \& Wit; Boyer et al.; Jones et al.). We found that catch-up growth was not possible after a substantial nutritive diet for a long period (six months). Despite the nutritional restoration through adequate calories, the current study found that the capacity for catch-up growth was diminished in malnourished rats. So, based on the present findings of an attenuated femoral dimensions, we confirm other researches (Houdjik et al., 2003; Oreffo et al.), even in malnourished rats (Houdjik et al., 2003; Cesani et al., 2003).

Interestingly, the studies on catch-up growth present a confusing mosaic of results. Several published reports document failed catch-up growth (Houdjik et al., 2003; Oreffo et al.), e.g., even in malnourished rats (Cesani et al.). There is an equally massive literature documenting successful catch-up growth (Boyer et al.; Andersen et al., 2005; Jones et al.), including growth restriction that occurred prenatally (Boyer et al.). Since growth dynamics are multifaceted, the methodological differences among studies prevent straightforward comparisons among these results. Recent reviews emphasize many variables affecting catchup growth, including length of growth restriction, type of growth restriction, and ontogenetic timing (Cesani et al.; Andersen et al.).

According to previous studies, the first week of life is a critical period regarding the nutritional status, and the weight of an animal at an early age can influence the food intake and body weight of that animal for the rest of its life. Therefore, the degree of malnutrition during the fetal or neonatal period can determine the extent to which there will be recovery of the nutritional status during the periods of growth and development(Lucas; Alippi et al.). Thus, it is well established in the literature that malnutrition in early life retards growth permanently in both humans and rats (Cooper et al.; Houdijk et al., 2003) and if this occurs during lactation it can lead to incomplete catch-up growth in adulthood.

In turn, the nutritional status of a relevant proportion of patients undergoing surgical procedures is far from ideal, and malnutrition can affect the outcomes of such procedures (Naber et al.; Correia \& Campos). Naber et al. found that $40 \%$ of the patients in a ward for nonsurgical patients were malnourished at admission, increasing the risk of subsequent complications in such patients.

The lactation is a critical period and the poor growth during infancy and childhood is associated with a poor mineral content and decreased bone mass (Rodriguez et al.; Cooper et al.; Medeiros et al.). Furthermore, the alterations in the mesenchymal stem cell function by the early environment may represent an important candidate mechanism for the programming of osteoporosis and associated consequences in later life (Oreffo et al.), e.g., an increased risk of fractures (Cooper et al.).

Protein-energy malnutrition during lactation promotes permanent damage to the bone structure of the pups, when this occurs, it can provoke incomplete catch-up growth in adulthood. Additionally, these results show that the proposed rat model is reliable for explaining the previous findings in pups (Fernandes et al., 2008), confirming the importance of an adequate dietary protein-energy concentration for mothers during lactation period for attaining normal bone composition and size of pups. In this paper, we provided important information for devising experiments and interpreting results when using the rat femur as a model for malnutrition, especially when making comparisons to human.

\section{CONCLUSION}

Our results show that protein and energy restriction during lactation leads to incomplete catch-up growth in adulthood. Morphometric analysis of the femur revealed a significant reduction in most of the parameters in the two treated groups, particularly the PER group, when compared to the controls.

\section{ACKNOWLEDGEMENTS}

This work was supported by grants from the National Council of Scientific and Technological Development $(\mathrm{CNPq})$ and the Foundation for Research Support of Rio de Janeiro (FAPERJ), Brazil. 
BABINSKI, M. S. D.; RAMOS, C. F.; FERNANDES, R. M. P.; CARDOSO, G. P. \& BABINSKI, M. A. Restricción alimentaria materna durante la lactancia conduce a la recuperación del crecimiento incompleto en el fémur de las crías en la edad adulta. Int. $J$. Morphol., 34(1):71-77, 2016.

RESUMEN: El objetivo de este estudio fue evaluar los efectos de la restricción de la proteína materna y de energía durante la lactancia, y analizar las dimensiones morfológicas si hubo recuperación del crecimiento a través de la nutrición normativa restaurada, así como en el eje mecánico del fémur de la descendencia en la edad adulta. En el parto, las crías de ratas Wistar fueron agrupadas aleatoriamente en los siguientes grupos: 1) control (C) - con acceso libre a una dieta estándar del laboratorio, que contenía $23 \%$ de proteínas; 2) con restricción de proteínas y energía (PER) - acceso libre a una dieta isoenergética, con restricción de proteínas, conteniendo un $8 \%$ de éstas y 3) grupo con restricción de energía, alimentado con restricción en la cantidad de alimento de la dieta estándar del laboratorio (ER). Al destete, todas las crías fueron separadas y recibieron las dietas establecidas hasta los 180 días (d180), luego fueron anestesiadas y sacrificadas. Las mediciones de los fémures de las crías de rata fueron obtenidas por puntos anatómicos preestablecidos. El análisis morfométrico de fémur demostró que la mayoría de las mediciones en los grupos ER y PER eran significativamente menores que las del grupo control, con mayores reducciones en el grupo PER. Nuestros resultados muestran que las restricciones de energía y proteínas durante la lactancia conducen a una recuperación del crecimiento incompleto en la edad adulta. El fémur mostró una reducción significativa en la mayoría de los parámetros en los dos grupos tratados, en particular el grupo de PER, en comparación con el grupo control.

PALABRAS CLAVE: Ratas; Fémur; Desnutrición; Crecimiento; Morfometría.

\section{REFERENCES}

Andersen, H. J.; Oksbjerg, N.; Young, J. F. \& Therkildsen, M. Feeding and meat quality - a future approach. Meat Sci., 70(3):543-54, 2005

Andrade, F. M.; Judice, L. F.; Cardoso, G. P.; Cisne, R.; Ramos, Cda. F. \& Babinski M. A. Maternal malnutrition during lactation in Wistar rats: effects on elastic fibers of the extracellular matrix in the trachea of offspring. J. Bras. Pneumol., 38(5):588-94, 2012.

Alippi, R. M.; Meta, M. D.; Olivera, M. I.; Bozzini, C.; Schneider, P.; Meta, I. F. \& Bozzini, C. E. Effect of protein-energy malnutrition in early life on the dimensions and bone quality of the adult rat mandible. Arch. Oral Biol., 47(1):47-53, 2002.

Barker, D. J. In utero programming of cardiovascular disease. Theriogenology, 53(2):555-74, 2000.

Bayne, K. Revised Guide for the Care and Use of Laboratory Animals available. American Physiological Society. Physiologist., 39(4):199, 208-11, 1996.

Brogan, R. S.; Fife, S. K; Conley, L. K.; Giustina, A. \& Wehrenberg, W. B. Effects of food deprivation on the GH axis: immunocytochemical and molecular analysis. Neuroendocrinology, 65(2):129-35,1997.

Boersma, B. \& Wit, J. M. Catch-up growth. Endocr. Rev., 18(5):64661, 1997.

Boyer, P. M.; Compagnucci, G. E.; Olivera, M. I.; Bozzini, C.; Roig, M. C.; Compagnucci, C. V. \& Alippi, R. M. Bone status in an animal model of chronic sub-optimal nutrition: a morphometric, densitometric and mechanical study. Br. J. Nutr., 93(5):663-9, 2005.
Cesani, M. F.; Orden, B.; Zucchi, M.; Muñe, M. C.; Oyhenart, E. E. \& Pucciarelli, H. M. Effect of undernutrition on the cranial growth of the rat. An intergenerational study. Cells Tissues Organs, 174(3):129-35, 2003.

Cooper, C.; Javaid, M. K.; Taylor, P.; Walker-Bone, K.; Dennison, E. \& Arden, N. The fetal origins of osteoporotic fracture. Calcif. Tissue Int., 70(5):391-4, 2002.

Correia, M. I.; Campos, A. C. \& ELAN Cooperative Study. Prevalence of hospital malnutrition in Latin America: the multicenter ELAN study. Nutrition, 19(10):823-5, 2003.

Engelbregt, M. J.; van Weissenbruch, M. M.; Lips, P.; van Lingen, A.; Roos, J. C. \& Delemarre-van de Waal, H. A. Body composition and bone measurements in intra-uterine growth retarded and early postnatally undernourished male and female rats at the age of 6 months: comparison with puberty. Bone, 34(1):180-6, 2004.

Fernandes, R. M. P.; Abreu, A. V.; Schanaider, A.; Soares Jr., E. R.; Pejanha, G. C. A.; Babinski, M. A. \& Ramos, C. F. Effects of protein and energy restricted diet during lactation leads to persistent morphological changes on tibia growth in the weaned pups. Int. J. Morphol., 25(3):565-71, 2007.

Fernandes, R. M.; Abreu, A. V.; Silva, R. B.; Silva, D. F.; Martinez, G. L.; Babinski, M. A. \& Ramos, C. F. Maternal malnutrition during lactation reduces skull growth in weaned rat pups: experimental and morphometric investigation. Anat. Sci. Int., 83(3):123-30, 2008.

Fetoui, H.; Mahjoubi-Samet, A.; Guermazi, F. \& Zeghal, N. Maternal low-protein diet affects bone mass and mineral metabolism in suckling rats. J. Anim. Physiol. Anim. Nutr. (Berl.), 92(4):448-55, 2008. 
Fischbeck, K. L. \& Rasmussen, K. M. Effect of repeated reproductive cycles on maternal nutritional status, lactational performance and litter growth in ad libitum-fed and chronically food-restricted rats. J. Nutr., 117(11):1967-75, 1987.

Houdijk, E. C.; Engelbregt, M. J.; Popp-Snijders, C. \& DelemarreVd Waal, H. A. Endocrine regulation and extended follow up of longitudinal growth in intrauterine growth-retarded rats. $J$. Endocrinol., 166(3):599-608, 2000.

Houdijk, M. E.; Engelbregt, M. T.; Popp-Snijders, C. \& Delemarre van der Waal, H. A. Long-term effects of early postnatal food restriction on growth hormone secretion in rats. J. P. E. N. J. Parenter. Enteral Nutr., 27(4):260-7, 2003.

Jones, D. C.; Bernstein, M. \& German, R. Z. Catch-up and targeted growth following variable duration protein restriction: effects on bone and body mass. J. Morphol., 272(4):485-96, 2011.

Lucas, A. Programming by early nutrition: an experimental approach. J. Nutr., 128(2 Suppl.):401S-406S, 1998.

Medeiros, D. M.; Plattner, A.; Jennings, D. \& Stoecker, B. Bone morphology, strength and density are compromised in irondeficient rats and exacerbated by calcium restriction. J. Nutr., 132(10):3135-41, 2002.

Mehta, G.; Roach, H. I.; Langley-Evans, S.; Taylor, P.; Reading, I.; Oreffo, R. O.; Aihie-Sayer, A.; Clarke, N. M. \& Cooper, C. Intrauterine exposure to a maternal low protein diet reduces adult bone mass and alters growth plate morphology in rats. Calcif. Tissue Int., 71(6):493-8, 2002.

Miller, J. P. \& German, R. Z. Protein malnutrition affects the growth trajectories of the craniofacial skeleton in rats. J. Nutr., 129(11):2061-9, 1999.

Naber, T. H.; Schermer, T.; de Bree, A.; Nusteling, K.; Eggink, L.; Kruimel, J. W.; Bakkeren, J.; van Heereveld, H. \& Katan, M. B. Prevalence of malnutrition in nonsurgical hospitalized patients and its association with disease complications. Am. J. Clin. Nutr., 66(5):1232-9, 1997.

de Onis, M.; Blössner, M. \& Borghi, E. Prevalence and trends of stunting among pre-school children, 1990-2020. Public Health Nutr., 15(1):142-8, 2012.

Oreffo, R. O.; Lashbrooke, B.; Roach, H. I.; Clarke, N. M. \& Cooper, C. Maternal protein deficiency affects mesenchymal stem cell activity in the developing offspring. Bone, 33(1):100-7, 2003.

Passos, M. C. F.; Ramos, C. F. \& Moura, E. G. Short and long term effects of malnutrition in rats during lactation on the body weight of offspring. Nutr. Res., 20(11):1603-12, 2000.

Ramos, C. F.; Lima, A. P.; Teixeira, C. V.; Brito, P. D. \& Moura, E. G. Thyroid function in post-weaning rats whose dams were fed a low-protein diet during suckling. Braz. J. Med. Biol. Res., 30(1):133-7, 1997.
Reeves, P. G.; Nielsen, F. H. \& Fahey, G. C. Jr. AIN-93 purified diets for laboratory rodents: final report of the American Institute of Nutrition ad hoc writing committee on the reformulation of the AIN-76A rodent diet. J. Nutr., 123(11):1939-51,1993.

Rodriguez, P. N.; Friedman, S. M.; Boyer, P. \& de Portela, M. L. Influence of dietary calcium concentration on body size and bone composition in rats during recovery from malnutrition. J. Am. Coll. Nutr., 17(1):86-91, 1998.

Teixeira, C.; Passos, M.; Ramos, C.; Dutra, S. \& Moura, E. Leptin serum concentration, food intake and body weight in rats whose mothers were exposed to malnutrition during lactation. J. Nutr. Biochem., 13(8):493, 2002.

Turner, C. H. Biomechanics of bone: determinants of skeletal fragility and bone quality. Osteoporos. Int., 13(2):97-104, 2002.

Waterland, R. A. \& Garza, C. Potential mechanisms of metabolic imprinting that lead to chronic disease. Am. J. Clin. Nutr., 69(2):179-97, 1999.

Correspondence to:

Prof. Dr. Marcio Antonio Babinski

Department of Morphology, Biomedical Center

Fluminense Federal University

Av. Prof. Hernani Mello 101

CEP 24.210-150

Niterói, Rio de Janeiro

BRAZIL

Email: mababinski@gmail.com

Received: 29-07-2015

Accepted: 02-01-2016 